UDC 539.3; 624.073.4

\title{
INVESTIGATION OF THE CONICAL TYPE SHELL STRUCTURE DYNAMICS UNDER INTERNAL AXISYMMETRIC PULSE LOADING
}

\author{
V.V. Gaidaichuk, \\ Doctor in Engineering Science \\ K.E. Kotenko, \\ $\mathrm{Ph}$. D. in Engineering Science \\ Kyiv National University of Construction and Architecture \\ 31 Povitroflotskyi ave., Kyiv 03680
}

DOI: $10.32347 / 2410-2547.2021 .107 .247-256$

\begin{abstract}
The impact assessment results of a three-layer truncate conical shell taper angle in its strainstress state under an internal axisymmetric pulse load are presented in the article. Impact of physical and mechanical characteristics of the polymer filler reinforced by discrete ribs has been considered. The shell taper angle impact on its strain-stress state has been determined, which corresponds to the length change of the pipe system transition section.

Key words: conical three-layer shell, conical angle, strain-stress state (SSS), polymer filler, finite element model, internal axisymmetric pulse load.
\end{abstract}

Introduction and problem statement. In modern engineering systems, the use of layered shell structures has increased significantly, allowing to reduce the weight and metal intensity in structures, with the purpose of ensuring their reliability and cost-effectiveness. Largely, this is facilitated by the studies of the stress-strain state of layered shells, which characterize the influence of geometrical, physical, mechanical, and other factors on the SSS of such structures [1-3]. Therefore, the determination of such factors and evaluation of the effectiveness of their influence can be significant for the use of layered shells.

In conical layered structures, the shell taper angle defined by the deviation of its generatrix from the vertical axis can be such a factor. A number of circumstances determine its value, including the change of the system's transition section length provided similar diameters of the connected elements or the change in the diameters of these elements given the constant length of the transition section. There is also an option when the shell taper angle changes provided the constant length of its generatrix. In this case, one of its diameters remains unchanged and the length of the transition section changes less significantly.

Taking into account the significant possibility of changing the value of the indicated factor and the limited information regarding the effectiveness of its impact on the stress-strain state of conical structures, the effect of changes in the taper angle value of a three-layer conical shell on its stress-strain state is being investigated under different physical and mechanical characteristics of its polymeric filler, which is reinforced with discrete ribs when an internal axisymmetric impulse load is applied to the shell. 
Investigation and analysis of obtained results. The research included analysis of theoretical aspects of the tapered structures' stress-strain state problem and numerical calculations of the displacements and stresses of tapered shell bearing layers as function of the value of its taper angle and the corresponding length of the forming tapered structure.

According to the theory of thin shells [4], modeling of vibrations of threelayered conical $[3,5]$ and cylindrical shells $[6,7]$, the deformed state of the structures' bearing layers is determined by the components of generalized vectors of displacements $\vec{U}_{1}=\left(u_{1}^{1}, u_{3}^{1}, \varphi_{1}^{1}\right)^{T}$ and $\vec{U}_{2}=\left(u_{1}^{2}, u_{3}^{2}, \varphi_{1}^{2}\right)^{T}$. The displacement of $u_{1}^{i}$ and $u_{3}^{i}$ bearing layers along the generatrix $S$ and the angle of rotation $\varphi_{1}^{i}$ at hourly moment $t$ in case of minor linear displacements are represented by the following dependences:

$$
\begin{aligned}
& u_{1}^{i}(s, z, t)=u_{01}^{i}(s, t)+z_{i} \varphi_{i}(s, t), \\
& u_{3}^{i}(s, z, t)=u_{03}^{i}(s, t), i=1,2
\end{aligned}
$$

where $z_{i}$ is a vertical coordinate of each bearing layer; $\varphi_{i}$ is a normal line angular deflection to the median surface of the bearing layer.

Application of the light filler reinforced by discrete ribs rigidly connected to the shell's coating features the displacement of the given layer $u_{1}^{t}(s, z, t)$ and $u_{3}^{t}(s, z, t)$ with the following dependencies:

$$
\begin{aligned}
& u_{1}^{t}(s, z, t)=\left(1+\frac{z_{t}}{R_{t s}}\right) u_{01}^{t}(s, t)+z_{t} u_{1}^{t}(s, t) ; \\
& u_{3}^{i}(s, z, t)=u_{01}^{i}(s, t) .
\end{aligned}
$$

Combining these dependences provides a theoretical determination of the displacements of the whole shell structure, and the use of the stationary action principle enables the control of forces and moments within the shell layers and reinforcement of ribs by means of relations (3) and (4).

a) for bearing layers:

$$
\begin{aligned}
& T_{11}^{i}=B_{11}^{i}\left(\varepsilon_{11}^{i}+v_{11}^{i} \varepsilon_{11}^{i}\right) ; T_{22}^{i}=B_{11}^{i}\left(\varepsilon_{11}^{i}+v_{11}^{i} \varepsilon_{11}^{i}\right) ; \\
& T_{13}^{i}=B_{13}^{i} \varepsilon_{13}^{i} ; M_{11}^{i}=D_{11}^{i} k_{11}^{i} ; T_{22}^{i}=B_{22}^{i} \varepsilon_{22 j}^{i},
\end{aligned}
$$

where:

$$
B_{11}^{i}=\frac{E_{i} h_{i}}{1-v_{i}^{2}} ; B_{13}^{i}=D_{13}^{i} k_{1}^{i} ; D_{11}^{i}=\frac{E_{i} h_{i}^{3}}{12\left(1-v_{i}^{2}\right)} ; B_{22 j}=E_{j} F_{j},
$$

b) for the light-weight filler:

$$
\begin{aligned}
& T_{11}^{t}=B_{11}^{t}\left(\varepsilon_{11}^{t}+v^{t} \varepsilon_{22}^{t}\right) ; T_{22}^{t}=B_{11}^{t}\left(\varepsilon_{11}^{t}+v^{t} \varepsilon_{11}^{t}\right) ; \\
& T_{13}^{t}=B_{13}^{t} \varepsilon_{13}^{t} ; M_{11}^{t}=D_{11}^{t} k_{11}^{t},
\end{aligned}
$$

where: 


$$
B_{11}^{t}=\frac{E_{t} h_{t}}{1-v_{t}^{2}} ; B_{13}^{t}=D_{13}^{t} k_{1}^{2} ; D_{11}^{t}=\frac{E_{t} h_{t}^{3}}{12\left(1-v_{t}^{2}\right)} .
$$

In equations (3) and (4) $E_{i} ; E_{t} ; D_{13}^{i} ; D_{13}^{t} ; v_{i} ; v_{t}, E_{j} ; v_{j}$ are parameters of physical and mechanical characteristics of the load-bearing layers' materials, light-weight filler and reinforcing ribs; $k_{1}^{2}$ is transverse shear coefficient in the theory of Timoshenko-type shells.

So, theoretical determination of the stress-strain state allows us to solve this problem for tapered layered structures. However, this process is rather laborintensive and, in some cases, requires nontrivial approaches. Therefore, the finite-element modeling method was used to determine the stress-strain state parameters of a conical structure.

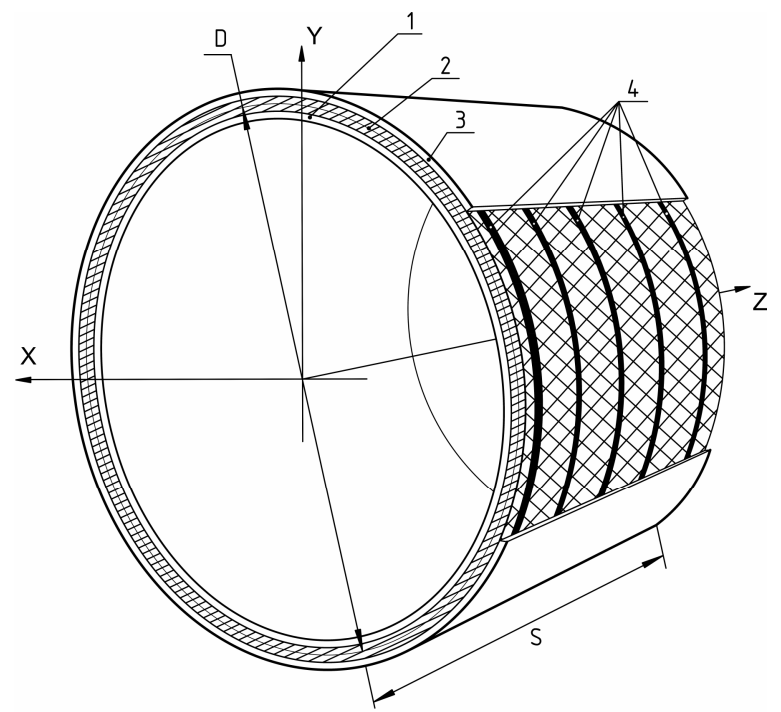

Fig. 1. Constructional design of a conical type three-layer shell:

1 - internal layer; 2 - filler; 3 - external layer; 4 - reinforcing ribs

A three-layer sheared conical structure (Fig. 1) with rigidly fixed ends was used for the studies. The taper angle effect at constant and variable lengths of the generatrix on the stress-strain state of the conical shell was considered. In first case, the length of generatrix $\mathrm{S}$ in the middle of shell layer was $295 \mathrm{~mm}$ and was constant, changing only the taper angle (from $\alpha=10^{\circ}$ to $\alpha=20^{\circ}$ ) and one of the diameters of the shell; in second case, the generatrix length was changed from $580 \mathrm{~mm}$ to $295 \mathrm{~mm}$ as a result of a similar taper angle change with constant diameters of elements connected by a conical structure.

The thickness of the sheathing layers was the same and was $h_{1}=h_{3}=10 \mathrm{~mm}$. The lightweight polymer filler was reinforced with 5 discrete ribs rigidly connected to the coatings and had a thickness of $h_{2}=0 \mathrm{~mm}$. The discrete reinforcing ribs were located at points 


$$
s_{j}=[6+(k-1) 16] * \Delta s, k=\overline{1,5}, \Delta s=\left(S-s_{0}\right) / 80 .
$$

The Young modulus ratio of the filler's and sheathing's materials corresponded to the following values $E_{1} / E_{3}=500$ and $E_{1} / E_{3}=50$. Their specified values were $E_{1}=E_{3}=70 \mathrm{GPa}, E_{T}=0.14$ and $1.4 \mathrm{GPa}$, and other indicators of physical and mechanical characteristics had the following values $\mu_{1}=\mu_{3}=0.3$, $\rho_{1}=\rho_{3}=2.7 \cdot 10^{3} \mathrm{~kg} / \mathrm{m}^{3}$. The diameters of the end cross sections of the studied shells in first case were $D=800 \mathrm{~mm}$ and $d=697.32 \mathrm{~mm}$ and $600 \mathrm{~mm}$, and in second case $D=800 \mathrm{~mm}$ and $d=600 \mathrm{~mm}$.

The boundary conditions corresponded to:

a) at $s=s_{0}$ :

$$
\begin{aligned}
& u_{1}^{i}\left(s_{0}, t\right)=0 ; u_{3}^{i}\left(s_{0}, t\right)=0, i=1.2 \\
& u_{1}^{i}(S, t)=0 ; u_{3}^{i}(S, t)=0, \quad i=1.2,
\end{aligned}
$$

b) zero-initial conditions at $t=0$ have been assumed as below:

$$
\begin{aligned}
& u_{1}^{i}(s, 0)=\frac{\partial u_{1}^{i}}{\partial t}(s, 0)=0, i=1.2 ; \\
& u_{3}^{i}(s, 0)=\frac{\partial u_{3}^{i}}{\partial t}(s, 0)=0, i=1.2 .
\end{aligned}
$$
below:

The distribution of an internal pulse load $Q$ has been implemented as

$$
Q(t)=A^{*} \sin \frac{\pi * t}{T},
$$

where: $A$ is the pulse power load amplitude; $T$ is the load duration; $t$ is the time interval.

The following loading parameters have been accepted: $A=10^{6} \mathrm{~Pa} ; T=$ $50 * 10^{-6} \mathrm{~s}$.

Distribution of displacements' and stresses' magnitudes along the spatial coordinate $S$ was determined by the software complex Nastran through the direct transient dynamic process algorithm within the time interval $0 \leq t \leq 10 T$. The time interval step duration was $0.25^{*} 10^{-6} \mathrm{~s}$ and the total number of steps was 200 . The detailed and accurate calculation results have determined the choice of the solid finite element type.

The finite element model (Fig. 2) with the generatrix length of $295 \mathrm{~mm}$ had 20060 solid finite elements and 24480 nodes, and with the length of $580 \mathrm{~mm}$ included accordingly 39440 of such elements and 47736 nodes.

In addition to the horizontal displacements (deflections) and stresses of the bearing layers of the analyzed conical structures, their first natural frequency $\left(f_{1}\right)$ was also calculated.

In a sheared conical structure with constant cross-section diameters $(D, d-$ const) and a variable length of the generatrix $S$ (depending on the taper angle), the distribution of displacements $U_{3}$ along the generatrix was the least contrasting, and their peak values were at $\alpha=10^{\circ}$ and the relation $E_{1.3} / E_{T}=500$. 
The maximum displacement value meeting these conditions was $29 \mathrm{~mm}$ and was observed at the timepoint 7T. The taper angle increase to a value of $\alpha=20^{\circ}$ and consequently decrease of the generatrix length from $580 \mathrm{~mm}$ to $295 \mathrm{~mm}$ has increased the uneven distribution of horizontal displacement and reduced its maximum value by almost $18 \%$.

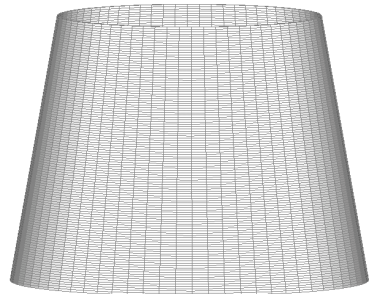

(a)

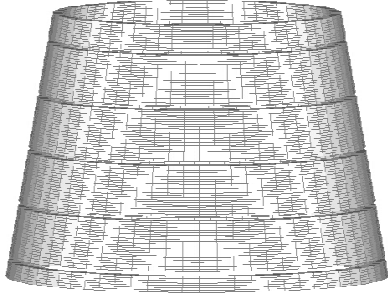

(c)

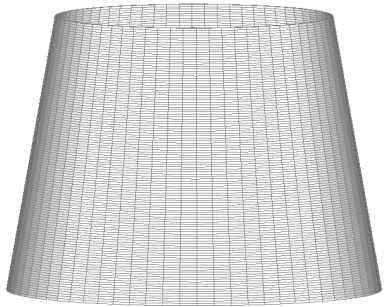

(b)

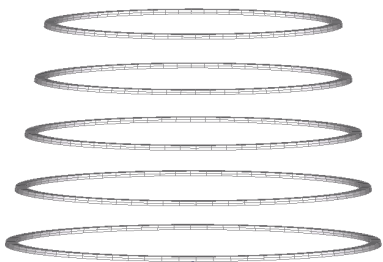

(d)

Fig. 2. The three-layer conical shell finite element model:

(a) - the loadbearing internal sheathing; (b) - the loadbearing external sheathing;

(c) - polymeric filler; (d) - reinforcing ribs

The first natural frequency of the shell in first case was $f_{1}=1072 \mathrm{~Hz}$, and in second case $-2074 \mathrm{~Hz}$. At the relation $E_{1.3} / E_{T}=50$ and taper angle $\alpha=10^{\circ}$, the displacement distribution along the generatrix corresponded qualitatively to its distribution, similarly to that at $E_{1.3} / E_{T}=500$, and its maximum value $26 \mathrm{~mm}$ was almost by $12 \%$ less than the similar value at $E_{1.3} / E_{T}=50$. In case of the taper angle increase to $20^{\circ}$ and the generatrix length reduction to $295 \mathrm{~mm}$, the distribution of displacement along the generatrix length was similar, and its maximum value $U_{3}$ was almost at the same level as the similar value. The natural frequency $f_{l}$ was $1154 \mathrm{~Hz}$ at the taper angle $\alpha=10^{\circ}$, and it was $2203 \mathrm{~Hz}$ at $\alpha=20^{\circ}$.

The obtained displacement results are presented in Tab. 1.

At a constant generatrix length $(S=295 \mathrm{~mm}$, Tab. 1$)$, the change from $10^{\circ}$ to $20^{\circ}$ of its inclination angle to the vertical axis has reduced by $21 \%$ the value of the maximum displacement of the outer load-bearing shell layer provided the relation $E_{1.3} / E_{T}=500$, and almost did not change the value of this displacement provided the relation $E_{1.3} / E_{T}=50$. 
Table 1

Maximal axial horizontal displacements $u_{1}^{i}$ of the shell sheathings with different physical and mechanical properties of the polymer filler at a timepoint $(t)$

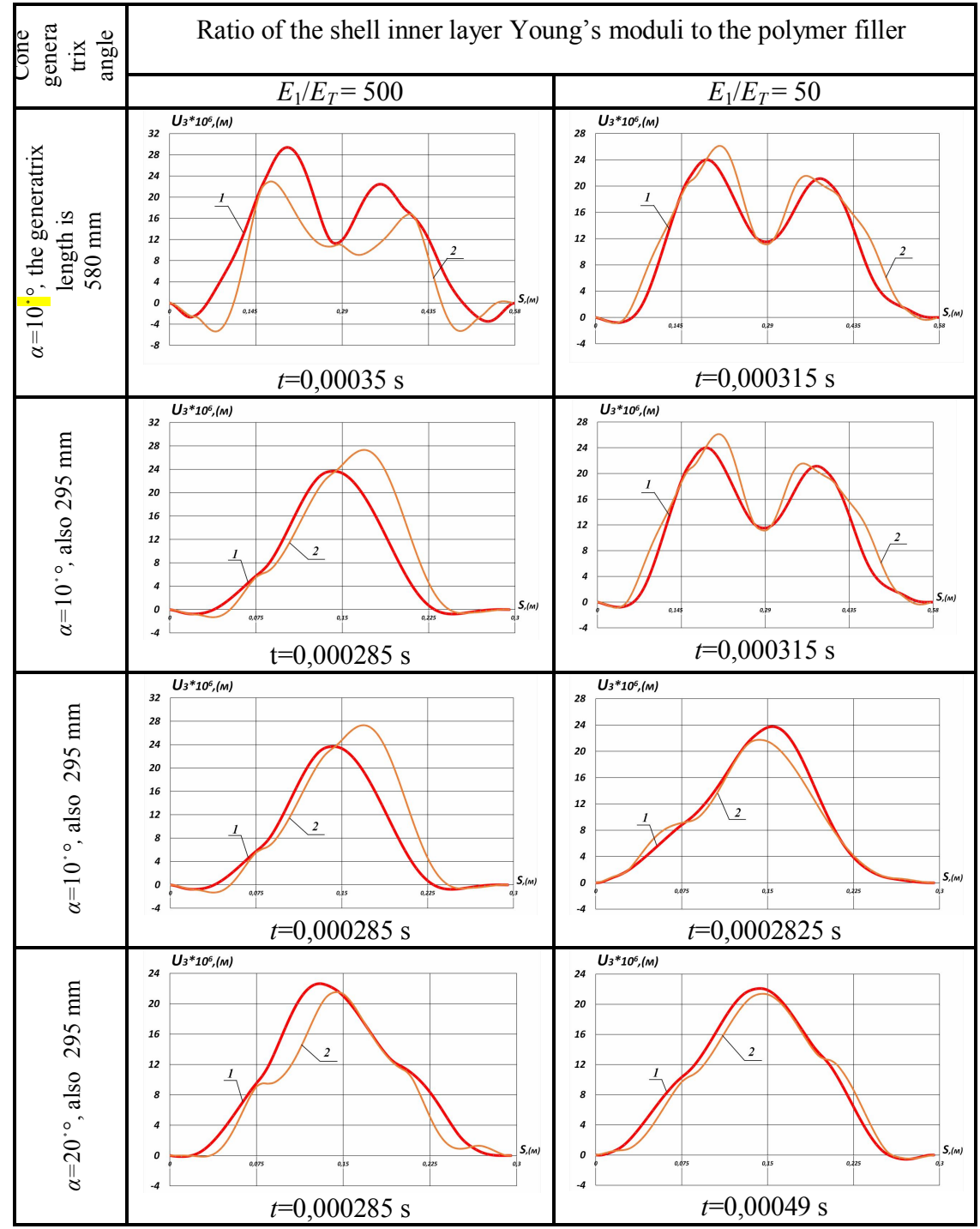

1 - shell internal layer; 2 - shell external layer

The impact of angle $\alpha$ change on the shell stress state was similar (Fig. 3). The maximum value of normal stress $\sigma_{y}$, which was determined in the inner bearing layer of the shell when the angle $\alpha$ has changed from $10^{\circ}$ to $20^{\circ}$, has 
decreased by $22 \%$ when the interrelation was $E_{1.3} / E_{T}=500$, and did not change when the interrelation was $E_{1.3} / E_{T}=50$. Changes in the shell taper angle had a different impact on the time of reaching the maximum stress values. At a constant length of the generatrix and the relation $E_{1.3} / E_{T}=50$, increase of the angle $\alpha$ by $10^{\circ}$ has increased the time required to reach the maximum stress, however remained unchanged at $E_{1.3} / E_{T}=500$.

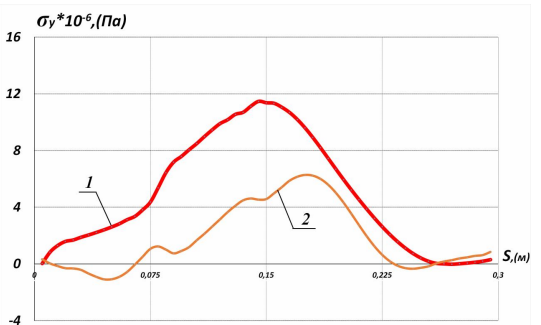

(a) $t=0,000285 \mathrm{~s}$

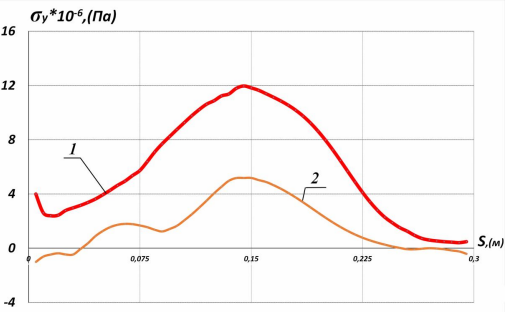

(b) $t=0,000285 \mathrm{~s}$

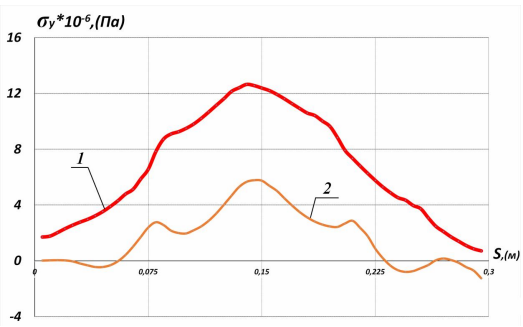

(c) $t=0,0002825 \mathrm{~s}$

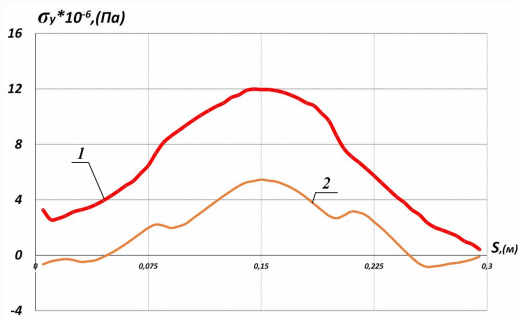

(d) $t=0,00049 \mathrm{~s}$

Fig. 3. Maximal stress $\sigma_{y}$ of the shell bearing layers

( 1 - of the internal layer, 2 - of the external layer) provided the generatrix length of $295 \mathrm{~mm}$ and different taper angle values: (a) at $E_{1} / E_{2}=500$ and $\alpha=10^{\circ}$; (b) at $E_{1} / E_{2}=50$ and $\alpha=10^{\circ}$;

(c) at $E_{1} / E_{2}=500$ and $\alpha=20^{\circ}$; (d) at $E_{1} / E_{2}=50$ and $\alpha=20^{\circ}$

Conclusions. The inclination angle increase of the conical layered shell generatrix reduces significantly the stress-strain state provided the Young's moduli ratio of the shell and filler bearing layers is $E_{1.3} / E_{T}=500$. The maximum displacements and stresses of the bearing layers have decreased by almost $20 \%$ when the angle $\alpha$ was doubled (from $10^{\circ}$ to $20^{\circ}$ ) and the generatrix length remained constant. The shell stress-strain state changed significantly when the generatrix length was increased and its inclination angle was reduced (from $20^{\circ}$ to $10^{\circ}$ ). Its maximum displacements and stresses have decreased by $18 \%$ and $22 \%$, respectively.

The use of polymeric filler with relation $E_{1.3} / E_{T}=50$ has practically eliminated impact of the generatrix shell inclination angle on the shell's stressed-strain state. 


\section{REFERENCES}

1. Lugovoi P. Z., Meish V. F., Meish Yu. A., Orlenko S. P. Dynamic Design of Compound Shell Structures of Revolution Under Nonstationary Loads // Intern. Appl. Mech. - 2020, 56, № 1 - P. 22-32.

2. Meish Yu.A., Orlenko S.P. K chislennomu raschetu nestatsionarnyih kolebaniy trehsloynyih tsilindrichnyih obolochek $\mathrm{s}$ poperechnyim diskretnyim rebristyim napolnitelem (To the numerical calculation of nonstationary vibrations of three-layer cylindrical shells with transverse discrete ribbed filler) // Actual problems of engineering mechanics: abstracts of the VI International Conference. -Odessa, May 20 - 24, 2019. - P.215 - 216

3. Meish V.F., Meish Y.A., Melnik V.M. Chyselne modeliuvannia dynamichnoi povedinky konichnoi obolonky zminnoi tovshchyny pry dii rozpodilenoho impulsnoho navantazhennia (Numerical modeling of the dynamic behavior of a conical shell of variable thickness under the action of a distributed impulse load) // Problems of computational mechanics and strength of structures: Coll. Science. wash. - Dnipropetrovsk: Lira, 2014. - Issue 22 - P.169-181.

4. Timoshenko S.P., Woinowsky-Krieger S. Theory of Plates and Shells. Second Edition. New York etc.: McGraw-Hill Book Company INC, 1959. 636 p.

5. Orlenko S.P. Chyselne modeliuvannia kolyvan trysharovoi konichnoi obolonky z dyskretnosymetrychnym neodnoridnym zapovniuvachem (Numerical simulation of oscillations of a three-layer conical shell with a discrete-symmetric inhomogeneous filler) //Dopov. Nac. Akad. Nauk. Ukr. №8 - 2020,- P. 35-42.

6. Lugovoi P. Z., Gaidaichuk V.V., Skosarenko Yu.V., Kotenko K.E. Napruzheno-deformovanyi stan trysharovykh tsylindrychnykh obolonok $\mathrm{z}$ armovanym lehkym zapovniuvachem pry nestatsionarnomu navantazhenni (Stress-strain state of the three-layer cylindrical shells with reinforced lightweight filler under nonstationary load) // International Applied Mechanics 2021, 57, № 4 - P. 1-14.

7. Gaidaichuk V.V., Kotenko K.E. Stress-strain state of a three-layer cylindrical shell under internal axisymmetric pulse load // Strength of Materials and Theory of Structures. - 2020. Issue. 105. - P. - 145-151.

Стаття надійшла 22.05.2021

Гайдайчук В.В., Котенко К.Е.

\section{ДОСЛІДЖЕННЯ ДИНАМІКИ ОБОЛОНКОВОЇ СТРУКТУРИ КОНІЧНОГО ТИПУ ПРИ ВНУТРІШНЬОМУ ОСЕСИМЕТРИЧНОМУ ІМПУЛЬСНОМУ НАВАНТАЖЕННI}

Наведені результати оцінки впливу кута конусності тришарової зрізаної конічної оболонки на іiі напружено-деформований стан під дією внутрішнього осесиметричного імпульсного навантаження. Враховано вплив фізико-механічних характеристик полімерного заповнювача армованого дискретними ребрами. Визначено вплив кута конусності оболонки на іiі напружено-деформований стан, відповідаючий зміні довжини перехідної ділянки трубної системи.

Ключові слова: конічна тришарова оболонка, кут конуса, напружено-деформований стан, полімерний заповнювач, скінченно-елементна модель, імпульсне внутрішнє осесиметричне навантаження.

\section{Gaidaichuk V.V., Kotenko K.E.}

\section{INVESTIGATION OF THE CONICAL TYPE SHELL STRUCTURE DYNAMICS UNDER INTERNAL AXISYMMETRIC PULSE LOADING}

The research included analysis of theoretical aspects of the tapered structures' stress-strain state problem and numerical calculations of the displacements and stresses of tapered shell bearing layers as function of the value of its taper angle and the corresponding length of the forming tapered structure. The taper angle effect at constant and variable lengths of the generatrix on the stress-strain state of the conical shell was considered.

The three-layer sheared conical structure with rigidly fixed ends was used for the studies. The thickness of the sheathing layers was the same and was $10 \mathrm{~mm}$. The lightweight polymer filler was reinforced with 5 discrete ribs rigidly connected to the coatings and had a thickness $20 \mathrm{~mm}$. 
In first case, the length of generatrix $\mathrm{S}$ in the middle of shell layer was $295 \mathrm{~mm}$ and was constant, changing only the taper angle (from $\alpha=10^{\circ}$ to $\alpha=20^{\circ}$ ) and one of the diameters of the shell; in second case, the generatrix length was changed from $580 \mathrm{~mm}$ to $295 \mathrm{~mm}$ as a result of a similar taper angle change with constant diameters of elements connected by a conical structure.

Distribution of displacements' and stresses' magnitudes along the spatial coordinate $\mathrm{S}$ was determined by the software complex Nastran through the direct transient dynamic process algorithm within the time interval $0 \leq t \leq 10 T$. The time interval step duration was $0.25 * 10^{-6} \mathrm{~s}$ and the total number of steps was 200 . The detailed and accurate calculation results have determined the choice of the solid finite element type.

In addition to the horizontal displacements (deflections) and stresses of the bearing layers of the analyzed conical structures, their first natural frequency $\left(f_{1}\right)$ was also calculated.

Key words: conical three-layer shell, conical angle, strain-stress state (SSS), polymer filler, finite element model, internal axisymmetric pulse load.

\section{Гайдайчук В.В., Котенко К.E.}

\section{ИССЛЕДОВАНИЕ ДИНАМИКИ ОБОЛОЧЕЧНОЙ СТРУКТУРЫ КОНИЧЕСКОГО ТИПА ПРИ ВНУТРЕННЕЙ ОСЕСИММЕТРИЧНОЙ ИМПУЛЬСНОЙ НАГРУЗКЕ}

Приведены результаты оценки влияния угла конусности трехслойной срезанной конической оболочки на ее напряженно-деформированное состояние при внутренней осесимметричной импульсной нагрузке. Учтено влияние физико-механических характеристик полимерного заполнителя армированного дискретными ребрами. Определено влияние угла конусности оболочки на ее напряженно-деформированное состояние при изменении длины переходного участка трубной системы.

Ключевые слова: коническая трехслойная оболочка, угол конусности, напряженнодеформированное состояние, полимерный наполнитель, конечно-элементная модель, импульсная внутренняя осесимметричная нагрузка.

Ключевые слова: коническая трехслойная оболочка, угол конуса, напряженнодеформированное состояние, полимерный заполнитель, конечно-элементная модель, импульсная внутренняя осесимметричная нагрузка.

\section{УДК 539.3}

Гайдайчук В.В., Котенко К.Е. Дослідження динаміки оболонкової структури конічного типу при внутрішньому осесиметричному імпульсному навантаженні // Опір матеріалів і теорія споруд: наук.-тех. збірн. - К.: КНУБА, 2021. - Вип. 107. - С. 247-256.

У статті наведені результати оцінки напружено-деформованого стану тришарової конічної оболонки, враховуючі ї̈ структурну особливість, фізико-механічні характеристики полімерного наповнювача, армованого дискретними ребрами.

Таб. 1. Іл. 3. Бібліогр. 7 назв.

\section{UDC 539.3}

Gaidaichuk V.V., Kotenko K.E. Investigation of the conical type shell structure dynamics under internal axisymmetric pulse loading/ Strength of Materials and Theory of Structures: Scientific-and-technical collected articles - Kyiv: KNUBA, 2021. - Issue 106. - P. 247-256.

The article presents the results of assessing the stress-strain state of a three-layer conical shell, taking into account its structural feature, physical and mechanical characteristics of a one-piece polymer filler reinforced with discrete ribs.

Tab. 1. Fig. 3. Ref. 7.

\section{УДК 539.3}

Гайдайчук В.В., Котенко К.Э. Исследование динамики оболочечной структуры конического типа при внутренней осесимметричной импульсной нагрузке // Сопротивление материалов и теория сооружений. - 2021. - Вып. 107. - С. 247-256.

В статье приведены результаты оценки напряженно-деформированного состояния трехслойной оболочки конического типа, учитывающие ее структурную особенность, физико-механические характеристики цельного полимерного наполнителя, армированного дискретными ребрами.

Табл. 1. Ил.3. Библиогр. 7 назв. 
Автор (вчена ступень, вчене звання, посада): доктор технічних наук, професор, завідувач кафедри теоретичної механіки Київського національного університету будівництва i архітектури Гайдайчук Віктор Васильович.

Адреса робоча: 03680 Украӥна, м. Київ, проспект Повітрофлотський, 31, к. 433, Київський національний університет будівництва $і$ архітектури, кафедра теоретичної механіки, Гайдайчуку Віктору Васильовичу.

Роб. тел. +380 (44) 241-55-72;

Моб. тел. +380 (97) 542-94-27;

e-mail: viktor_gaydaychuk@bigmir.net

ORCID ID: https://orcid.org/0000-0003-2059-7433

Автор (вчена ступень, вчене звання, посада): кандидат технічних наук, доцент кафедри теоретичної механіки Київського національного університету будівництва і архітектури Котенко Костянтин Едуардович.

Адреса робоча: 03680 Украӥна, м. Київ, проспект Повітрофлотський, 31, к. 433, Київський національний університет будівництва $і$ архітектури, кафедра теоретичної механіки, Котенку Костянтину Едуардовичу.

Роб. тел. +380 (44) 241-55-72;

Моб. тел. +380 (95) 585-20-76;

e-mail: 1969box@mail.ru

ORCID ID: https://orcid.org/0000-0002-3181-3819 